\title{
AISTIMODULAATION HYÖDYNTÄMINEN MIELENTERVEYSKUNTOUTUKSESSA - AISTIMODULAATIOHUONEEN SUUNNITTELU
}

\section{Aisteja hyödyntämällä voidaan muuttaa omaa olotilaa}

Aistimuksiin perustuvat interventiot ovat kasvattaneet suosiotaan mielenterveystyössä maailmanlaajuisesti. Toimintaterapeutit esimerkiksi Australiassa ja Uudessa-Seelannissa ovat hyödyntäneet aistimodulaatiota (sensory modulation) mielenterveystyössä (Brown ym. 2019, Scanlan \& Novak 2015). Menetelmä on todettu tehokkaaksi, mutta Suomessa se on vielä melko tuntematon. Aistimodulaatio on terapeuttinen interventio, joka auttaa henkilöä muuttamaan olotilaansa aistitoimintojen avulla. Sopivia aistitoimintoja hyödyntämällä henkilö pystyy muun muassa säätelemään tunteita ja vireystilaa, lisäämään mielihyvää, hallitsemaan riippuvuuksia sekä opettelemaan omien tarpeiden tunnistamista. (Fitzgibbon \& O'Sullivan 2018.) Hoitokoti Peltola 0y:n projektina on ollut aistimodulaation jalkauttaminen hoitokodin arkityöhön. Osana projektia Turun ammattikorkeakoulun toimintaterapeuttiopiskelijat saivat opinnäytetyön toimeksiannoksi suunnitella mielenterveyskuntoutujien asumispalveluyksikköön aistimodulaatiohuoneen (sensory modulation room), jota voidaan hyödyntää jatkossa asukkaiden kuntoutumisen tukena. Peltolassa jalkauttamisen osa-alueita ovat lisäksi olleet henkilökunnan kouluttaminen, aistimodulaatiopakettien luominen sekä arviointimenetelmien kehittäminen.

\section{Taustaa}

Mielenterveyden häiriöitä sairastavilla on usein hermostollisesti poikkeavaa aistitiedon käsittelyä (Bailliard \&t Whigham 2017, Adams-Leask ym. 2018, Harrison ym. 2019). Esimerkiksi skitsofrenian on todettu vaikuttavan kaikkiin aistitoimintoihin, suurimmat häiriöt ovat näkö- ja kuuloaistin alueella. Lisäksi skitsofrenia-asiakkaiden proprioseption - eli asento- ja liikeaistin - häiriöt voivat johtaa motorisiin häiriöihin, jotka osaltaan voivat johtaa puutteelliseen kehonhahmotukseen ja itsensä tiedostamiseen. (Lipskaya-Vlikovskya ym. 2015, Harrison ym. 2019.) Aistitiedon käsittelyn haasteet vaikuttavat jokapäiväiseen elämään. Tutkijat ovat myös saaneet viitteitä siitä, että aistitiedon käsittelyn ongelmat tuottavat korkeamman tason kognitiivisia ongelmia, kuten keskittymisvaikeuksia ja ongelmanratkaisun tai itsesäätelyn haasteita. (Bailliard \& Whigham 2017.) Aistimusten avulla ylläpidetään her- 
moston normaalia toimintaa (Champagne 2018).

\section{Aistimodulaatio ja sen hyödyntämi- nen mielenterveyskuntoutuksessa}

Aistimuksiin perustuvat interventiot ovat tutkitusti tehokas keino auttaa psykiatrisessa hoidossa olevia hallitsemaan oireita, kuten ahdistuneisuutta ja masentuneisuutta (Wallis ym. 2018, Knight ym. 2010). Aistimodulaatiota voidaan hyödyntää asiakkaiden kanssa, joilla on esimerkiksi keskittymisvaikeuksia, kipuja tai haasteita sosiaalisissa suhteissa, tunteiden säätelyssä, motoriikassa tai ongelmanratkaisussa. Sopivia aistitoimintoja hyödyntämällä henkilö pystyy muun muassa säätelemään tunteita ja vireystilaa sekä lisäämään mielihyvää, sillä aistimukset vaikuttavat suoraan keskushermostoon vaikuttaen olotilaan. (Fitzgibbon \&t O’Sullivan 2018.) Esimerkiksi tuntoaistin merkitys on suurempi kuin usein ajatellaan. Taktiilinen aistijärjestelmä on laajin ihmisen aistijärjestelmistä ja vaikuttaa voimakkaasti sekä fyysiseen että psyykkiseen toimintaan. Tuntoaistin lähettämät impulssit keskushermostoon voivat tiedostamatta auttaa ihmistä esimerkiksi sääte- lemään vireystilaa, liikkumaan tehokkaasti ja vaikuttamaan tunteisiin. (Ayres 2008.)

Aistimodulaatio on niin sanottu bottom-up-menetelmä, jonka avulla vaikutetaan aivojen fysiologiaan kehosta tulevien aistimusten kautta. Menetelmä voi tarjota ratkaisuja niille, joilla on vaikeita oireita ja sairauksia (Knight ym. 2010) ja joiden taidot eivät riitä korkean tason kognitiiviseen prosessointiin. (Fitzgibbon \& O'Sullivan 2018, Adams-Leask ym. 2018.) Interventiossa traumataustojen huomioiminen on erityisen tärkeää, sillä aistimukset voivat laukaista uudelleen muistoja traumaattisista kokemuksista (Fitzgibbon \&t O'Sullivan 2018). Usein henkilöt muokkaavat olotilaansa aistimusten avulla kiinnittämättä siihen erityistä huomiota (Champagne \& Stromberg 2004). Mielenterveyskuntoutujat eivät välttämättä tunnista oman kehonsa tarpeita, joten he saattavat tarvita ohjausta tarkoituksenmukaisten aistimusten hyödyntämiseen. Aistimodulaatiota voidaan hyödyntää lukuisilla eri tavoilla osana terapeuttista suhdetta. Se voi olla esimerkiksi aistivälinepakkauksen tai aistitilojen hyödyntämistä. Terapeuttisessa suhteessa voidaan myös luoda yhdessä asiakkaan kanssa suunnitelma siitä, kuinka

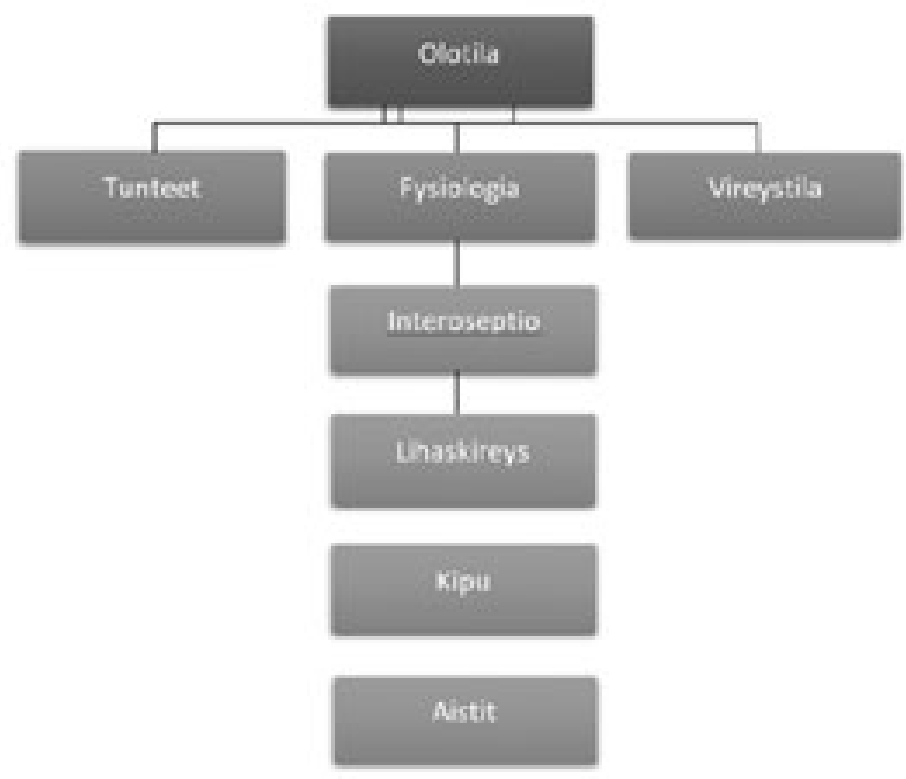

Kuvio 1. Olotilaan vaikuttavat tekijät. Mukailtu ja vapaasti suomennettu teoksesta: Sensory modulation - Resource Manual (Fitzgibbon \& O’Sullivan 2018). 
aistimuksia hyödynnetään päivän aikana. Aistimodulaatiota voisi siis kutsua myös tavoitteelliseksi aistimuksen hyödyntämiseksi. Menetelmän tavoitteena on erilaisten strategioiden siirtyminen arkeen. Ymmärrys asiakkaan sensorisista mieltymyksistä auttaa löytämään kaikkein tehokkaimmat keinot olotilan muuttamiseen aistimusten avulla (Champagne 2018). Olotila koostuu tunteista, vireystilasta ja fysiologisista tekijöistä (kuvio 1). Aistimodulaatiolla voidaan vaikuttaa niihin kaikkiin, sillä ne ovat vahvasti yhteydessä toisiinsa.

\section{Opinnäytetyönä aistimodulaatio- huoneen suunnitteleminen}

Aistihuoneiden suosio on kasvanut kansainvälisesti psykiatrisella kentällä (Champagne Et Stromberg 2004). Aistihuone tarkoittaa fyysistä tilaa, joka vastaa asiakkaan aistitarpeisiin ja kykyihin. Se on suunniteltu varta vasten tarjoamaan aistikokemuksia turvallisesti, ja sitä voidaan käyttää esimerkiksi voimaantumiseen ja taitojen oppimiseen. (Champagne \& Sayer 2014.) Opinnäytetyön tavoitteena oli kehittää näyttöön perustuva aistimodulaatiohuoneen suunnitelma, jonka toimeksiantaja voi toteuttaa haluamassaan aikataulussa. Aistimodulaatiohuoneella tarkoitetaan huonetta, jossa hyödynnetään aistimodulaation teoriaa. Tarkoituksena oli, että aistimodulaatiohuonetta voisi käyttää vaihtoehtoisena menetelmänä lääkehoidon rinnalla. Aistihuoneiden käyttö voi jäädä vähäiseksi, jos siihen ei saada riittävästi koulutusta tai sen suunnitteluprosessi ei osallista henkilökuntaa ja asiakkaita (Barbic ym. 2019). Tämän vuoksi opinnäytetyöprosessiin kuului sekä henkilökunnan että asiakkaiden osallistaminen. Valmis suunnitelma sisältää pohjapiirustuksen, välineet, hankintapaikat ja hinnat sekä huoneeseen tarkoitetut turvallisuus- ja hygieniaohjeet.

\section{Pohdinta}

Aistimodulaatio on vasta pikkuhiljaa rantautumassa Suomeen. Aistimodulaatio voi tarjota lukuisia mahdollisuuksia terapiasuhteeseen tai jopa yhteiskunnallisen hyvin- voinnin lisäämiseen. Aistimodulaation hyödyntäminen ei ole ammattiin sidottu, vaan monet eri ammattiryhmät voisivat hyötyä aistimusten syvällisemmästä ymmärryksestä ja niiden vaikutuksesta ihmisen käyttäytymiseen. Aistimuksia olisi hyvä hyödyntää jatkossa enemmän mielenterveyskuntoutuksessa myös Suomessa. Aistitiloja voisi kehittää lisää erilaisiin palvelutaloihin. Myös sairaaloissa voisi olla aistitila esimerkiksi päiväsalin yhteydessä tuomaan piristystä mieleen tai helpotusta kipuihin. Kehittyvää teknologiaa voisi hyödyntää aistihuoneissa monella tavalla, esimerkiksi virtuaaliteknologian, kuten VR-lasien, muodossa. Kun hyödyntää aistimodulaatiota terapeuttisena menetelmänä, on tärkeää perehtyä ensin huolellisesti sen teoriaan ja aistijärjestelmien fysiologiaan. Siksi olisikin tärkeää, että Suomessa järjestettäisiin koulutuksia aistimodulaatiosta.

\section{Opinnäytetyön tiedot:}

Eerola J, Löfgren M, Pykälä-Aho A (2020) Aistimuksilla muutosta mieleen: aistimodulaatiohuoneen suunnitteleminen mielenterveyskuntoutujille. Toimintaterapeuttikoulutus. Turun ammattikorkeakoulu. Opinnäytetyö.

Opinnäytetyöhön voit tutustua tästä linkistä: https://www.theseus.fi/bitstream/ handle/10024/336615/Janette $\% 20$ Eerola $\% 2 \mathrm{c} \% 20$ Marika\%20 L\%c3\%b6fgren\%2c\%20Antti\%20 Pyk\%c3\%a4l\%c3\%a4-Aho.pdf?sequence $=$ 2EtisAllowed $=y$

Irina Katajisto-Korhonen, toimintaterapeutti (Yamk), ammatillinen opettaja, Turun ammattikorkeakoulu / Hoitokoti Peltola Oy

Helena Tigerstedt, THM, ett, lehtori, Turun ammattikorkeakoulu

Janette Eerola, toimintaterapeuttiopiskelija (AMK)

Marika Löfgren, toimintaterapeuttiopiskelija (AMK)

Antti Pykälä-Aho, toimintaterapeuttiopiskelija (AMK) 


\section{Lähteet}

Adams-Leask K, Varona L, Dua C, Baldock M, Gerace A, Muir-Cochrane E (2018) The benefits of sensory modulation on levels of distress for consumers in a mental health emergency setting. Australasian Psychiatry 26, 5, 514-519. Viitattu 10.03.2020. https://doi.org/10.1177/1039856217751988

Ayres AJ (2008) Aistimusten aallokossa: sensorisen integraation häiriö ja terapia. PS-kustannus, Jyväskylä.

Bailliard AL, Whigham SC (2017) Linking neuroscience, function and intervention: A scoping review of sensory processing and mental illness. American Journal of Occupational Therapy.

Barbic S, Chan N, Rangi A, Bradley J, Pattison R, Brockmeyer K, Leznoff S, Smolski Y, Toor G, Bray B, Leon A, Jenkins M, Mathias S (2019) Health provider and service-user experiences of sensory modulation rooms in an acute inpatient psychiatry setting. PLOS ONE.

Brown A, Tse T, Fortune T (2019) Defining sensory modulation: A review of the concept and a contemporary definition for application by occupational therapists. Scandinavian journal of oc-cupational therapy 26, 7, 515-523. Viitattu 23.3.2020. https://doi.org/10.1080/11038128.201 8.1509370

Champagne T (2018) Sensory modulation in dementia care: assessment and activities for sensory-enriched care. Jessica Kingsley Publishers, London \& Philadelphia.

Champagne T, Sayer E (2014) The effects of the use of the sensory room in psychiatry. Viitattu 30.10.2019. https://www.ot-innovations.com/ wp-content/uploads/2014/09/qi_study_sensory_room.pdf
Champagne T, Stromberg N (2004) Sensory approaches in inpatient psychiatric settings: innovative alternatives to seclusion \& restraint. SLACK Incorporated, Thorofare, New Jersey.

Fitzgibbon C, 0'Sullivan J (2018) Sensory Modulation: Changing how you feel through using your senses. Sensory Modulation Brisbane, Australia.

Harrison L, Kats A, Williams M, Aziz-Zadeh L (2019) The Importance of Sensory Processing in Mental Health: A Proposed Addition to the Research Domain Criteria (RDoC) and Suggestions for RDoC 2.0. Frontiers in psychology. Vol. 10. Article 103.

Knight M, Adkison L, Kovach JS (2010) A comparison of multisensory and traditional inter-ventions on inpatient psychiatry and geriatric neuropsychiatry units. SLACK Incorporated. Thorofare, New Jersey.

Lipskaya-Vlikovskya L, Bar-Shalitaa T, Barta 0 (2015) Sensory modulation and daily-life participation in people with schizophrenia.

Scanlan J, Novak T (2015) Sensory approaches in mental health: A scoping review. Australian occupational therapy journal 62, 5, 277-85. Teoksessa S Barbic, N Chan, A Rangi ym. (2019) Health provider and service-user experiences of sensory modulation rooms in an acute inpatient psychiatry setting. PLOS ONE.

Wallis K, Sutton D, Bassett S (2018) Sensory Modulation for People with Anxiety in a Community Mental Health Setting. Taylor \&t Francis Ltds. 